Geosci. Model Dev. Discuss., 1, 243-283, 2008 www.geosci-model-dev-discuss.net/1/243/2008/ (C) Author(s) 2008. This work is distributed under the Creative Commons Attribution 3.0 License.

The Aral Sea shrinking by a 3-D model ECOSMO

I. Alekseeva and C. Schrum

\title{
Historical reconstruction of the Aral Sea shrinking by a full 3-D wetting and drying model ECOSMO
}

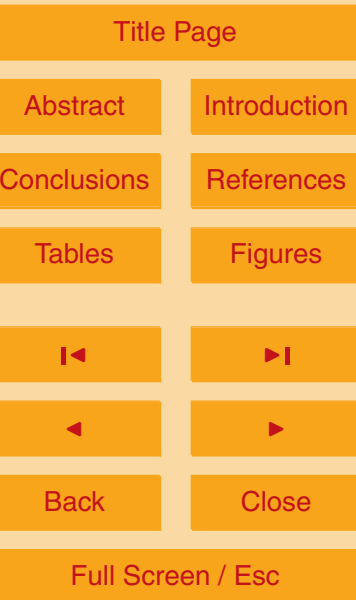

Published by Copernicus Publications on behalf of the European Geosciences Union. 


\section{Abstract}

Several decades ago, the Aral Sea was the fourth out of the biggest lakes all over the world. Due to intense irrigation in the Aral Sea basin an imbalance in the water budget occurred and caused dramatic shrinking of the Aral Sea. With the present paper a 5 sea-ice model for the Aral Sea has been developed, aiming in resolving the long-term development of the sea including drastic volume and surface area changes. The necessary requirement for such a model is a mass conservative wetting and drying scheme which has been developed in the application. By performing sensitivity experiments on different implementations of wetting and drying schemes, a significant influence of wag-

gling on the volume and salt budget was identified for a hindcast under realistic forcing and the need for a volume and mass conserving scheme was demonstrated. Using a mass conserving implementation a model hindcast was performed for 1979-1993 by using the ECMWF re-analysis (ERA-15) meteorological data and modeled evaporation. Consideration of surface area changes in a temporal resolution of the model time step allowed for a realistic description of non-linear interactions between volume loss and evaporation changes. The sea-ice model was able to successfully simulate sea level and sea surface area decrease as well as sea-ice dynamics on a multiyear to decadal time scale. Model predicted evaporation was found to result in significantly improved volume budgets for the Aral Sea and in realistic predictions of the Aral Sea shrinking.

20 Furthermore, by comparing the simulated average salinities to observed ones, it could be shown that the present model concept neglecting additional salt flux effects such as salt precipitation and salinity deposition on the dried sea bed, is adequate to reproduce observed mean salinities during the period of investigation.

\section{Introduction}

25 In the 1960s of the XX century the Aral Sea, which is located in Central Asia on the territories of the republics of Kazakhstan and Uzbekistan was the fourth out of the
The Aral Sea shrinking by a 3-D model ECOSMO

I. Alekseeva and C. Schrum

\section{Title Page}

Abstract Introduction

Conclusions

Tables References Figures

14

Back

Full Screen / Esc

Printer-friendly Version

Interactive Discussion 
biggest lakes all over the world. The area of the lake covered about $70000 \mathrm{~km}^{2}$ (e.g. Peneva et al., 2004; EU INTAS Aral Sea 1014 report, 2004) and at that time its water volume was approximately about $1070 \mathrm{~km}^{3}$ (Zavialov et al., 2003). In the past 4 decades the Aral Sea has undergone dramatic changes. Due to an imbalance in the

5 water budget caused by increased river water use for irrigation, the Aral Sea lost a major part of its water volume and its sea surface level dropped down by almost $23 \mathrm{~m}$ (Zavialov et al., 2003). As a consequence the sea surface area shrank dramatically. Presently the sea water surface of the Large Sea covers only about $15000 \mathrm{~km}^{2}$, which is approximately only $21 \%$ of the initial sea water surface area. During its shrinking 10 the Aral Sea lake has separated into 2 independent basins, the Large and Small Seas (e.g. Salokhiddinov and Khakimov, 2004; Zavialov et al., 2003). The volume loss of the Aral Sea had severe consequences for the mineralization of the lake. In the 1960s the Aral Sea water was characterized as fresh water dominated with salinities around $10 \%$. Recent measurements in the Large Sea found salinity values dramatically increased: salinities between 80-95\%。 have been reported in November 2002 (Zavialov et al., 2003) and up to 110\%。 in August 2002 (Friedrich and Oberhänsli, 2004). These environmental changes impacted on the ecosystem, and resulted in drastic changes in species compositions, making commercial fisheries in the Aral Sea impossible (Aladin and Williams, 1993). Furthermore, decreasing sea level and increasing sea salinity 20 impact on the groundwater-seawater exchange and groundwater mineralization (e.g. discussed by Järsjo and Destouni, 2004). The volume loss and surface decrease furthermore influenced the pathways of moisture from sea to the atmosphere and resulted in changes of the local climate (Small et al., 2001).

Consequences of environmental changes in the Aral Sea region were enormous. 25 Economic, health and water resource problems of local inhabitants are the most dramatic ones. Especially the need for groundwater resources management led to an increased scientific interest and to increased number of international scientific projects carried out recently (for some references see Peneva et al., 2004; Salokhiddinnov and Khakimov, 2004). Major aspects of recent projects was the development of methods

The Aral Sea shrinking by a 3-D model ECOSMO

I. Alekseeva and C. Schrum

Title Page

Abstrac

Conclusions

Tables

Figures

14

4

Back

Full Screen / Esc

Printer-friendly Version

Interactive Discussion 
and tools to forecast and scenario test different water management strategies. Understanding of past environmental changes in the Aral Sea region is still limited. As Peneva et al. (2004) pointed out, the scientific challenge is not only the understanding of the causes of changes but as well the reconstruction of what had really happened.

5 Historical reconstructions are required and even necessary because of lacking environmental observations. After 1980s there was a breakdown of the observational network developed by the Soviet Union. Existing monitoring network was not adapted to the environmental changes in the Aral Sea region. For example, stations measuring river discharge were previously located near river mouths but currently they are hundreds 10 kilometres away from the shore. Thus, the actual river discharge into the sea is unknown since most of the water is lost on its way to the sea shore (e.g. Peneva et al., 2004).

There are great uncertainties in estimates of other components of the Aral Sea water budget. Earlier estimations of groundwater runoff showed its little contribution to 15 the total water balance (Sadov and Krasnikov, 1987). Hence, groundwater was often neglected in water balance estimations (e.g. Small et al., 1999). However, recent results indicated a high probability for increasing importance of groundwater for the Aral Sea water balance (Järsjo and Destouni, 2004; Peneva et al., 2004). Uncertainties in estimates of evaporation and precipitation are also critical for closing the water budget. 20 Presently, data on evaporation and precipitation with high temporal resolution are only available from global atmospheric re-analysis data sets such as ERA-15 (Gibson et al., 1996), ERA-40 (Uppala et al., 2005) and NCEP (Kalnay et al., 1996). However, these data have well known drawbacks and insufficient spatial resolution (of 100-250 km) to describe local process in the Aral Sea region.

25 Within the international EU-INTAS project "Study of the Groundwater Contribution to the Aral Sea Region Water Supply and Water Quality: Strategies for Reversibility and Pollution Control", a full 3-D hydrodynamic sea-ice model (ECOSystem Model, ECOSMO) of the Aral Sea lake has been developed to contribute to predictive capacities in the Aral Sea region. The present investigation employs the model with a mass

\section{GMDD}

$1,243-283,2008$

The Aral Sea shrinking by a 3-D model ECOSMO

I. Alekseeva and C. Schrum

Title Page

Abstract

Conclusions

Tables

14

4

Back Introduction References Figures $>1$

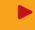
Close

Full Screen / Esc

Printer-friendly Version

Interactive Discussion 
conserving wetting and drying scheme, which has been implemented to simulate the rapid volume and surface area change and its consequence for the Aral Sea water and salt budget. Another full 3-D hydrodynamic model of the Aral Sea has been introduced previously by Sirjacobs et al. (2004). However, the applicability of this model was 5 limited due to wetting and drying scheme has not been implemented for this model. Hence, the model was used only to study the circulation and transport conditions for a given range of sea surface level.

In this paper we present the sea-ice model ECOSMO and aim in the historical reconstruction of the Aral Sea shrinking during 1979-1993 and in the model validation for the 10 period. Since most of available observations are annual estimates of averaged in the Aral Sea characteristics and do not provide a basis for a validation of highly resolved modeled fields we avoid demonstrating typical 3-D results. We also used satellite derived data to evaluate modeled ice, the only multiyear observations which provide a view on spatial-temporal dynamics in the Aral Sea.

15 The paper is structured as following. In Sect. 1, the sea-ice model ECOSMO and its setup for the Aral Sea are described. Implementation of a wetting and drying scheme with respect to its application for water budget modeling in realistic natural conditions is also discussed in Sect. 1. The sea-ice model has been repeatedly integrated for the period 1979-1993. In a first step, the model has been used to calibrate poor known components of the Aral Sea water budget by a water balance consideration and thereby to improve available expert estimates of precipitation and runoff; as it is describes in Sect. 3. Then, the derived "best guess" estimates were used for a final model hindcast. In Sect. 4, we describe model results and perform a validation of the model in terms of averaged water budget components and salinity and sea-ice dynamics. Section 5 is

The Aral Sea shrinking by a 3-D model ECOSMO

I. Alekseeva and C. Schrum

Title Page

Abstract Introduction

Conclusions

Tables References Figures

14

4

Back

Full Screen / Esc

Printer-friendly Version

Interactive Discussion 


\section{Methods and data}

\subsection{Model description}

The Aral Sea model is based on the hydrodynamic part of the ECOSMO model system (Schrum and Backhaus, 1999; Schrum et al., 2006), a general state of the art 3-D 5 hydrodynamic-sea-ice model which has previously been used for different shelf sea applications (e.g. Schrum, 1997a; Harms et al., 2005). The model uses the hydrostatic approach and the UNESCO International non-linear equation of state (Fofonoff and Millard, 1983). Turbulence is parameterized using an analytical $k-\varepsilon$ scheme for the vertical direction (Schrum, 1997b). Additionally, the sea-ice model consists of an ice module of Hibler-type (including viscous-plastic rheology and ice thermodynamics) and predicts actual air-sea turbulent fluxes based on meteorological data and modeled sea surface temperature as described by Schrum and Backhaus (1999).

The model is a z-level model with free surface and operates on an Arakawa C-grid. The model has implemented a free surface and a variable bottom layer thickness, allowing minimal bottom layer thickness dropping down to $1 \mathrm{~cm}$. It has been applied to the Aral Sea with a horizontal resolution of $5 \mathrm{~km}$ and 20 vertical levels with the maximum vertical resolution of $2 \mathrm{~m}$ in the upper $20 \mathrm{~m}$ layer of the water column. Lower layer boundaries are set at $24,28,32,36,40,45,50,55,60$ and $65 \mathrm{~m}$. The time step used for the model integrations was set to $10 \mathrm{~min}$. The model topography was constructed from a high resolution bottom topography $(700 \mathrm{~m})$ which originally was produced by S. Stanichniy (Marine Hydrophysical Institute, Ukraine) and his group (Fig. 1).

\subsection{Initial and boundary conditions}

Initial conditions were homogeneous distributions of salinity of $15.05 \%$ and temperature of $4^{\circ} \mathrm{C}$. Although not spatially resolved, these conditions provide the best available guess of the actual salinity conditions in the Aral Sea at January 1979 and the climatic estimate of average water temperature in January.

The Aral Sea shrinking by a 3-D model ECOSMO

I. Alekseeva and C. Schrum

\section{Title Page}

Abstract Introduction

Conclusions

Tables References Figures

14

4

Back

Full Screen / Esc

Printer-friendly Version

Interactive Discussion 
The sea-ice model was forced by atmospheric boundary conditions. For the present setup we used global coarse resolution re-analysis data provided by the European Centre for Medium-Range Weather Forecasts (ECMWF), i.e. the ERA-15 data (Gibson et al., 1996). However, turbulent air-sea fluxes are often biased in global atmospheric 5 data as a result of assimilation processes and are furthermore a function of coarse scale underlying boundary conditions. The long-wave radiation is also a function of local environmental conditions including sea surface temperature, atmospheric humidity and cloudiness. In 3-D global atmospheric data, such as ECMWF data, long-wave radiation is usually biased by uncertainties in atmospheric vertical stratification and huo midity by lacking information on actual sea surface temperature. Therefore we did not use them for the present study rather air-sea turbulent fluxes and long-wave radiation were calculated during integration of the sea-ice model at each model time step as described below.

Air-sea turbulent fluxes (fresh water, heat and impulse fluxes) are calculated by a 15 scheme based on Monin-Obukhov similarity theory, firstly presented by Launiainen and Vinma (1990). The fluxes are derived from modeled SST and ECMWF ERA-15 atmospheric boundary conditions including $2 \mathrm{~m}$ temperature and dew point temperature and $10 \mathrm{~m}$ wind speeds. The turbulent exchange coefficients are thereby a function of atmospheric stability and are found from an iteration procedure performed to estimate the

. Long-wave radiation was derived from well established parameterizations using modeled sea surface temperature and air temperature by a flux method (Idso and Jackson, 1969).

Global radiation was also calculated in the sea-ice model by using a cloud dependent 25 radiation model (Dobson and Smith, 1988) and albedo calculated as a function of solar inclination.

\section{GMDD}

1, 243-283, 2008

The Aral Sea shrinking by a 3-D model ECOSMO

I. Alekseeva and C. Schrum

Title Page

Abstract Introduction

Conclusions

Tables

References Figures

14

4

Back

Full Screen / Esc

Printer-friendly Version

Interactive Discussion 
To allow for a simulation of the Aral Sea surface level drop, which was of approximately $10 \mathrm{~m}$ for the considered 15 year period, and to account for corresponding changes of the sea surface area, a wetting and drying scheme has been implemented into 5 the sea-ice model. The aim was to develop a method which is robust to allow for a long-term numerical simulation. Besides, the method is required to be mass and salt conservative to accurately reconstruct historical changes in the Aral Sea including $60 \%$ of the evaporated lake volume and the corresponding salinity increase from 15 to $36 \%$.

Wetting and drying processes are common in the coastal ocean zones influenced by 10 tides and winds. There is a variety of wetting and drying schemes implemented in different 1-D and 2-D hydrodynamic models. Recently the technique of wetting and drying has been implemented in Princeton Ocean Model and can be directly applicable for 3-D hydrodynamic models which use terrain-following sigma-coordinate on the $C$-grid (Oey et al., 2007). Technique of wetting and drying implemented for hydrodynamics models with the fixed z-level vertical grid, such as ECOSMO, has been previously used for the modeling of hydrodynamics in tidal flats (e.g. Backhaus 1976; Hübner and Backhaus, 1996). However, due to discrete and fixed steps in z-level grids, mass imbalances and numerical instabilities are typically introduced when moving water body interacts with the dry area (e.g. Leendertse, 1987).

$20 \quad$ Balzano (1998) has reviewed a set of different wetting and drying schemes using 1-D and 2-D test cases. The author suggested that the best performance has a scheme which considers a linearly decreasing wet surface within a grid cell. However, since such a scheme requires iterations and therefore is significantly more computational expensive, it is not practical for use in a 3-D model application intended for a multi 25 decadal integration in time. Second best performances were found for systems basing the wet/dry status changes of a grid cell on sea level changes and differences between neighboring cells rather than using the undisturbed water depth changes. In the best performing schemes introduced by Balzano, the decision on whether a cell is wet or

The Aral Sea shrinking by a 3-D model ECOSMO

I. Alekseeva and C. Schrum

Title Page

Abstract

Conclusions

Tables

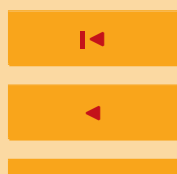

Back

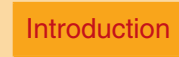

References

Figures

$>$ I

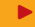

Close

Printer-friendly Version

Interactive Discussion 
dry is based only on the upstream direction, which is near by hand when focusing on dynamic flooding and drying. The application of the here presented model is however somewhat different. With respect to the Aral Sea problem we concentrate as well on drying or wetting as a consequence of air-sea water fluxes. Hence, we decided to 5 develop and test a slightly different scheme compared to those which have been tested by Balzano.

The ECOSMO wetting and drying scheme was developed on a basis of a z-level fixed model grid, which implies an introduction of thresholds controlling the flooding or wetting of model cells as a consequence of water level variations. The wet or dry 10 status of a grid cell $(i, j)$ is recognized by comparing its water column thickness $\left(h_{i, j}\right)$ and given threshold values. In case of a wet cell $h_{i, j}$ is found from the water depth $\left(H_{i, j}\right)$ and the time dependent deviation of sea surface level $\left(\xi_{i, j}\right)$, both are accounted for relative a zero sea surface level:

$h_{i, j}=H_{i, j}+\xi_{i, j}$

15 Dry cells are treated in the model as land cells and thus $\xi_{i, j}$ is undefined. In this case, to obtain $h_{i, j}$ we involve surrounding wet cells and define the mean of sea level deviations $\left(\overline{\xi_{i, j}}\right)$ :

$h_{i, j}=H_{i, j}+\frac{\xi_{i+1, j}+\xi_{i-1, j}+\xi_{i, j+1}+\xi_{i, j-1}}{4}=H_{i, j}+\overline{\xi_{i, j}}$

A check for the status of grid cells is executed on each model time step. The values for the thresholds were chosen after model sensitivity tests and a discussion following below in the text. We introduced different threshold values for wetting and drying processes. A cell changes its status to dry in case its water column thickness becomes less than the first threshold value which is set to $10 \mathrm{~cm}$. The cell status alternates from dry to wet in case of the water thickness $h_{i, j}$ exceeds the second threshold value of $2515 \mathrm{~cm}$. All wet cell even if they become dry on the next model time step are calculated by the full set of model equations. When a cell becomes wet it is initialized with zero
GMDD

$1,243-283,2008$

The Aral Sea

shrinking by a 3-D model ECOSMO

I. Alekseeva and C. Schrum

Title Page

Abstract Introduction

Conclusions

Tables

References

Figures

14

4

Back

Full Screen / Esc

Printer-friendly Version

Interactive Discussion 
velocities and to define magnitudes for other prognostic model variables the mean is derived over neighboring wet cells.

We introduced a certain window between the first and second thresholds aiming to avoid waggling, a numerical instability associated with repeatable oscillations of the 5 cell status, which is a common problem when thresholds are used in a wetting and drying scheme (Leendertse, 1987; Balzano, 1998). Furthermore, employing thresholds implies artificial removing/adding of relatively small volumes when drying/wetting of model grid cells occurs. Thus, inevitable errors are introduced into the total volume of a model domain. Modeled heat and salt budgets are also affected.

10 One can estimate a bias arising in the Aral Sea water budget due to using thresholds in the model simulation by a following simple calculation. During the Aral Sea shrinking in the considered period 1979-1993, the observed decrease of the sea surface area and the corresponding loss in the total sea volume accounted for $19.7 \times 10^{3} \mathrm{~km}^{2}$ and $402 \mathrm{~km}^{3}$, respectively. Since the mean square of a model grid cell is approximately $1525 \mathrm{~km}^{2}$, approximately 780 cells are expected to become dry at the end of the simulation. When a cell becomes dry, the artificial volume loss associated with the threshold of $10 \mathrm{~cm}$ accounts for $0.0025 \mathrm{~km}^{3}$ as a maximum. Finally, the bias in total volume accounts for $1.95 \mathrm{~km}^{3}$. That is less than $0.5 \%$ of the total sea volume decrease observed in the period. The bias is relatively small with respect to expected errors in the total volume balance due to uncertainties in forcing data. Hence, a threshold value of $10 \mathrm{~cm}$ seems to be uncritical.

However, the calculation given above is valid only in case of a continued sea surface level drop whereas local sea level variations are common for natural conditions. Natural sea level variations in conjunction with numerical instability arising due to the threshold method may lead to amplifying waggling. The latter might result in persistent artificial increase in the total sea volume because of artificial volume losses in case of drying are always less than the artificial volume gains in case of wetting. The error in the total volume can be decreased by using two different threshold values set for drying and wetting.

The Aral Sea shrinking by a 3-D model ECOSMO

I. Alekseeva and C. Schrum

\section{Title Page}

Abstract

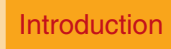

Conclusions

Tables

References

Figures

14

Back

Full Screen / Esc

Printer-friendly Version

Interactive Discussion 
Model sensitivity tests were performed to identify threshold values for wetting and drying processes which may allow for more accurate simulations of the Aral Sea variability influenced by realistic conditions. The period January-March 1979 was chosen as a test period. Different combinations of threshold values as presented in Table 1 5 were tested. We used time-series of sea surface level estimated from a balance version of the model as a reference to assess the accuracy of different numerical treatments. In the balance model version the water balance was only accounted for, thermodynamics and dynamics were neglected. Thus predicted reference sea level ("Balance SSL") comprises spatially undisturbed temporal variations of sea level and can be compared 10 with the surface averaged sea level (SSL) derived from the full version of the model. For test study we used observational data of river runoff, precipitation and evaporation were taken from ECMWF data.

Results of the test study are displayed in Fig. 2. They show that after 3 months of simulation a maximum deviation between simulated SSLs and "Balance SSL" of about $151.5 \mathrm{~cm}$ is obtained from the experiment 2. By a simple extrapolation (neglecting variability in forcing) for the 15 years period, this deviation might accumulate up to $90 \mathrm{~cm}$, which is about $10 \%$ of the observed Aral Sea level drop for the period. Comparing resultant SSL time-series between experiments 1 and 4, 2 and 5, 3 and 6 (each couple uses the same wet threshold but different dry thresholds) it can be shown that the model accuracy slightly increases with decreasing value of the dry threshold from 10 to $5 \mathrm{~cm}$. However, it needs to be taken into account that decreasing the wet threshold leads to less model stability. The comparison also demonstrates that the model solution is significantly more sensitive to a range between wet and dry thresholds than to absolute values of the thresholds. It is getting more accurate with increasing the 25 range. The maximum range of $35 \mathrm{~cm}$ is set in experiment 6 , which has the best performance; while the worse results derived from experiment 2 are associated with the zero range. This relationship is directly related to better suppression of waggling in case of the range is large. Waggling can be identified as an important process in sea level variations from pronounced high frequency oscillations of the SSL curves, particularly

\section{GMDD}

1, 243-283, 2008

The Aral Sea shrinking by a 3-D model ECOSMO

I. Alekseeva and C. Schrum

Title Page

Abstract

Conclusions

Tables

Figures

14

4

Back

Full Screen / Esc

Printer-friendly Version

Interactive Discussion 
in experiment 2. Although the increasing of wet threshold up to $40 \mathrm{~cm}$ and more may successfully reduce waggling and thus the associated volume imbalance, estimations of sea surface area changes might be biased by too high thresholds. Taking this into account for the long-term run we used wet and dry threshold values from experiment 1 , 5 i.e. 15 and $10 \mathrm{~cm}$, respectively.

From the sensitivity experiments it is clear that artificial sinks and sources due to using thresholds violate volume conservation and create significant deviations in the water balance even in the experiment with the best performance. Similar consequences can be expected for the salt balance. Different strategies to ensure the volume and 10 salt mass conservation are possible. A method, which involves redistribution of volume/salt from a drying grid cell over surrounding wet cells and removing an equivalent volume/salt from those in case of wetting of inner cells, can be implemented into the model. However, this kind of parameterizations introduce strong disturbance and instabilities in the model and require iteration methods for solving, making them com15 putationally time consuming (Balzano, 1998). To avoid these numerical problems, we enable a global compensation for the artificial volumes: redistribution of the volume equivalent to artificial volume losses/gains from drying/wetting grid cells equally over the water basin the cells are connected with. Isolated water domains may appear during the Aral Sea shrinking, the algorithm developed allows for the individual compensating scheme for each of them. However, arising small isolated water bodies are neglected.

A control experiment to assess efficiency of the global compensation method was carried out with the same conditions used for the test study described above. The resulting sea level time-series for the period January-March 1979 are shown in Fig. 3. Despite a large range of SSL variability in the Large and Small Aral, the basins connected by a narrow strait, derived variability of SSL in the total Aral Sea is almost identical with "Balance SSL". Therefore, volume conservation for the present implementation of wetting and drying is proved. The same technique of the global compensation was successfully used to enable the conservation of salt (not shown).

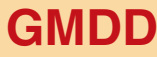

$1,243-283,2008$

The Aral Sea shrinking by a 3-D model ECOSMO

I. Alekseeva and C. Schrum

Title Page

Abstract

Conclusions

Tables

14

4

Back Introduction References Figures > Close Full Screen / Esc Printer-friendly Version Interactive Discussion 
In case of a long-term simulation of the Aral Sea dynamics, a model is intended to simulate a sea surface level drop of $10 \mathrm{~m}$ and more. This task is unusual and implies that the sea level drops below the first z-level of the model grid. Most numerical z-level models may simulate variability of sea level limited by the first model vertical 5 level. For instance, the tidal flat model applications (e.g. Hübner and Backhaus, 1996). The range of sea level variability which can be simulated by a model increases with a decrease of the model vertical resolution. In the present study we also aim in resolving vertical stratification and therefore the vertical model resolution of $2 \mathrm{~m}$ in the upper layer is chosen and thus in its original configuration the model may describe a 10 sea level lowering up to $2 \mathrm{~m}$ only. To allow for simulating the Aral Sea level drop an algorithm for shifting the vertical model grid has been developed. Prognostic 3-D fields are interpolated into a new location of grid nodes with respect to conservation lows. Since the maximum observed annual surface level drop in the Aral Sea is clearly less than $2 \mathrm{~m}$, the vertical re-setting of the model grid is necessary only once per year. In

the long-term run 1979-1993, the grid was vertically moved in the beginning of each year. The magnitude of the vertical grid movement was estimated in each separated water basin as the area averaged sea level obtained in the end of previous modeled year. The annual vertical down shifts of about $0.5-1.2 \mathrm{~m}$ avoid an overlap of local SSL and the lower boundary of the first vertical model level.

\subsection{Data and uncertainties}

In order to carry out the long-term model simulation for 1979-1993 and validate the sea-ice model we consider the Aral Sea water balance and involve observational data including estimates of the Aral Sea water budget components. Additionally, we aim in the validation of the multi-year model run in terms of thermo- and hydrodynamics. 25 However, the only available data appropriate for this purpose are annual time-series of salinity averaged in the Aral Sea (Mamatov et al., 2004) and sea-ice satellite data (Kouraev et al., 2004).

The volume income into the Aral Sea is the result of freshwater fluxes from river

\section{GMDD}

1, 243-283, 2008

The Aral Sea shrinking by a 3-D model ECOSMO

I. Alekseeva and C. Schrum

\section{Title Page}

Abstract

Conclusions

Tables

14

4

Back

Full Screen / Esc

Printer-friendly Version 
runoff, precipitation and groundwater inflow. Decreasing volume is the consequence of evaporation. The water balance equation of the Aral Sea can be expressed as:

$\Delta V / \Delta t=P+R+G W-E$

with $\Delta V$ is the volume change over time $\Delta t . P, R, G W$ and $E$ are the rates of precipi5 tation, river runoff, groundwater discharge and evaporation.

Observational data on sea surface level variability (e.g. annual time-series provided by Chub, 2000) and in particular obtained by satellite altimetry (Stanev et al., 2004; Peneva et al., 2004) provide reliable information. Corresponding changes in sea volume and sea surface area can be estimated from topographic data sets by consider10 ation of hypsometric relations. However, the estimates may differ depending on the topographic data used. In Fig. 4, the hypsometric relations for the Aral Sea basins are presented as derived by different authors in comparison with those derived from the model topography (see Fig. 1). These relations based on the model topography are similar to hypsometric relations presented by Stanev et al. (2004).

15 Despite extremely strong changes reported in hydrological and meteorological conditions in the Aral Sea region, corresponding existing data provide a poor basis to quantify the terms on the right side of Eq. (3). Efforts undertaken to quantify the Aral Sea water balance terms using observational based data (e.g. Bortnik, 1996) as well as model based studies (e.g. Small et al., 1999; Benduhn and Renard, 2004) resulted 20 in great uncertainties. A detailed discussion summarizing the knowledge on the water budget terms was provided earlier by a number of authors (e.g. Bortnik, 1996; Sirjacobs et al., 2004; Benduhn and Renard, 2004). Here, in Table 2 we tabulated estimates of precipitation, river runoff and evaporation including these public estimates, ECMWF ERA-15 data and the data recently provided by Mamatov et al. (2004).

25 Evaporation is the major water balance term in the Aral Sea. However, it is difficult to determine by direct measurements or calculations with sufficient accuracy. Using observed sea level changes, precipitation and assumptions on river runoff, irrigation and groundwater runoff, evaporation over the Aral Sea is typically were estimated by closing

The Aral Sea shrinking by a 3-D model ECOSMO

I. Alekseeva and C. Schrum

Title Page

Abstract

Conclusions

Tables

Figures

14

4

Back Full Screen / Esc

Printer-friendly Version

Interactive Discussion $\rightarrow 1$

Close 
the water balance (Bortnik, 1996; Mamatov et al., 2004) and thus is the most weakest part of the Aral Sea water budget. Its quantification is influenced by errors in all other parts of the water budget and furthermore influenced by deviations in hypsometric relations. Alternatively, evaporation can be estimated from model results such as global 5 re-analysis (Gibson et al., 1996; Kalnay et al., 1996). However, turbulent fluxes are typically biased due to inconsistencies in boundary forcing and in case of the re-analysis data are additionally influenced by assimilation schemes. With the coarse resolution in the order of $1^{\circ}-2^{\circ}$, the SST boundary values used in the analysis are typically not resolving any regional structures in the Aral Sea. Although the relative uncertainty in 10 evaporation is smaller (Table 2), they turn to be the most uncertain part of the water budget in absolute values with the potential range of up to $16 \mathrm{~km}^{3} \mathrm{yr}^{-1}$. Alternatively, evaporation can be derived from the sea-ice model itself by using the model routine for approximation of air-sea turbulent fluxes (see description above). We expect that predicted by the model evaporation has great advantage in comparison with other data. 15 The model calculates evaporation over the sea model grid on each model time step in respect with atmospheric conditions and actual sea surface temperature. Thus the modeled evaporation reflects local meso-scale thermo- and hydrodynamic processes including vertical stratification as simulated by the 3-D full sea-ice model with a high spatial resolution.

20 Estimates of precipitation are commonly biased by well known uncertainties from observational methods. Additional uncertainties arise due to observations are taken mainly from land stations and rarely over the sea. Precipitation data from different sources (Table 2) deviate by a factor of 2, including ERA-15 data (Gibson et al., 1996) reaching the upper level between the estimates. Pronounced uncertainties with the similar factor between lowest and highest estimates were found as well for river runoff.

Early estimations of the Aral Sea groundwater inflow range between 3 and $5.5 \mathrm{~km}^{3} \mathrm{yr}^{-1}$ (Khodjibaev, 1968; Chernenko, 1987), depending on the Aral Sea surface level. Groundwater contributions from selected sources were also estimated by a number of other authors (Glazovsky, 1995; Ferrari et al., 1999; Veselov, 2002) to

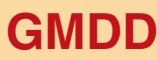

$1,243-283,2008$

The Aral Sea shrinking by a 3-D model ECOSMO

I. Alekseeva and C. Schrum

Title Page

Abstract

Conclusions

Tables

Figures

14

4

Back

Full Screen / Esc

Printer-friendly Version

Interactive Discussion 
vary in the range $0.07-0.27 \mathrm{~km}^{3} \mathrm{yr}^{-1}$. More recently Benduhn and Renard (2004) calculated the groundwater inflow by using a coupled mathematical model of salt and water balance in the rage $0.5-15 \mathrm{~km}^{3} \mathrm{yr}^{-1}$. Upper and lower bounds of groundwater inflow using groundwater modeling with different evaporation scenarios were predicted 5 by Järsjo and Destouni (2004). They predicted the groundwater inflow to be between $0-5 \mathrm{~km}^{3} \mathrm{yr}^{-1}$ before 1960s with continuously increasing groundwater inflow up to an upper boundary for potential groundwater inflow of about $30 \mathrm{~km}^{3} \mathrm{yr}^{-1}$ in the beginning of the 1990s.

For the current study estimations based on observational data of runoff, precipitation 10 and evaporation were also provided by Mamatov et al. (2004). These data were available as part of the Aral Sea Information System (ASIS) compiled and synthesized in the frame of the EU-INTAS project Aral Sea-1014 "Study of the Groundwater Contribution to the Aral Sea Region Water Supply and Water Quality: Strategies for Reversibility and Pollution Control" and the EU-INTAS project Aral Sea-1003 "Study of the Subsur15 face Water Role in Water Resources of the Aral Sea Region: Ecological Policy, Assessment and Prediction" (Annual Cluster Project Report, EU-INTAS-1003 and 1014, 2004). Monthly means for Amu Darya and annual means for Syr Darya were measured at hydrological stations (Kiziljar and Kazalinsk) presently located about $100 \mathrm{~km}$ away from the coast line. The potential loss of the river water on the way from the last 20 measurement station to the sea is currently unclear. From investigations of Mamatov et al. (2004) a potential loss between $50-100 \%$ of measured runoff was assumed to be possible, indicating that values typically considered in literature are potentially too high.

The discussion above summarized knowledge on historical processes in the Aral 25 Sea. It was shown that the great uncertainties exist in estimates of water budget components and only limited information on the Aral Sea hydrodynamics are available. It becomes evident that none of estimates of water budged components can be directly used to force the sea-ice model. However, the sea-ice model allows for prediction of the water balance, evaporation and thermo- and hydrodynamics as a function of precipita-

GMDD

1, 243-283, 2008

The Aral Sea shrinking by a 3-D model ECOSMO

I. Alekseeva and C. Schrum

Title Page

Abstract

Conclusions

Tables

Figures

14

4

Back

Full Screen / Esc

Printer-friendly Version

Interactive Discussion $\rightarrow$

ose 
tion and runoff only. It is possible to reconstruct the Aral Sea water balance involving predictive model potentials and available estimates. In order to carry out a historical reconstruction of the Aral Sea water balance components and effectively use available observational data for the model validation we develop a strategy described below.

\section{Model strategy}

We used independent estimates of the Aral Sea water balance components and the sea-ice model in order to reconstruct the water budget for 1979-1993. We consider ECMWF ERA-15 6-hourly re-analysis data (Gibson et al., 1996) on precipitations and river runoff data (Mamatov et al., 2004) as a basis for the reconstruction of these budget components. Then using model predicted evaporation we repeatedly integrated the sea-ice model to reach equilibrium between the modelled sea surface level and corresponding observed values over the period 1979-1993. For the reference we used annual time-series of sea level averaged over the Aral Sea surface area (Chub, 2000) and satellite derived estimates (Stanev et al., 2004; Peneva et al., 2004), which also provide an information on a different behavior of sea surface level in the Large and Small basins after they became separated in 1991. Hence, it was possible to calibrate original precipitation and runoff data in order to derive their "best guess" estimates via the iterative process by closing the water budget and in respect with other available estimates. We call resultant run as the "best guess" model run implying that it provides one of possible solutions for precipitation and runoff.

We assume that there is an advantage in utilizing ECMWF ERA-15 precipitation for model simulations; the data have the highest spatial-temporal resolution among other estimates and describe proper variably of large-scale precipitation due their potential to capture large-scale signals. Although ECMWF ERA-15 data overestimate precipitations (see Table 2) in the Aral Sea region, we believe to improve their absolute magnitudes by a constant correction factor aiming to retain variability. Following Sirjacobs et al. (2004) we used estimates of annual precipitation as compiled by Bortnik (1996) to

The Aral Sea shrinking by a 3-D model ECOSMO

I. Alekseeva and C. Schrum

Title Page

Abstract

Conclusions

Tables

14

4

Back Introduction References Figures $\rightarrow$ I $\checkmark$ Close Full Screen / Esc Printer-friendly Version Interactive Discussion 
derived an approximate measure for the necessary reduction of ERA-15 precipitation. In addition, we investigated ERA-15 precipitation data in terms of seasonal cycle. In Fig. 5, ERA-15 monthly means for 1979-1993 are compared with climatic data derived from different sources (Climate Analysis Center; climatic data from Legates and Will5 mot, 1990, and results of RegCM2 model as it was presented by Small et al., 1999). In addition, annual time-series of ERA-15 precipitation were also compared with corresponding estimates of Mamatov et al. (2004) (see Fig. 6). It becomes evident that ERA-15 data are well above the climatological estimates and the estimated annual means. A reduction of ERA-15 precipitation in order of $60 \%$, i.e. by a factor 0.4 , gives 10 on averaged approximately $5 \mathrm{~km}^{3} \mathrm{yr}^{-1}$ (see Fig. 6) and seems appropriate to fit ERA-15 precipitation to estimates provided by Bortnik (1996) as well as corrected ERA-15 data approach to climatic monthly mean data (Fig. 5).

We also aim in deriving constant correction factors to decrease river runoff data for Amu Darya and Syr Darya rivers (Mamatov et al., 2004) which were already shown to 15 overestimate actual runoff into the Aral Sea. Due to great uncertainties in estimates of both river runoff and groundwater, we could not distinguish between them when performing model simulations. Therefore, for this study we consider the runoff to be estimated from the model as a combined river runoff-groundwater freshwater inflow; in the following we refer to the joint river-groundwater runoff as runoff. It is possible 20 to determine constant reduction factors which are individual for Amu Darya and Syr Darya rivers by a consideration of water budgets of Large and Small Aral Sea after the separation of the basins.

After a number of the sea-ice model simulations, which can be considered as iterative steps in order to approach modelled sea surface level variability to observed variability by modifying input data (precipitation and river runoff), we derived a final "best guess" long-term model run. As a result constant correction factors for ERA-15 precipitation and river runoff data (Mamatov et al., 2004) were obtained as well as corresponding dataset of modelled evaporation. Linea reduction factors were identified to be 0.4 for ERA-15 precipitation, 0.4 for Amu Darya and 0.8 for Syr Darya.

The Aral Sea shrinking by a 3-D model ECOSMO

I. Alekseeva and C. Schrum

Title Page

Abstract

Conclusions

Tables

14

4

Back

Full Screen / Esc

Printer-friendly Version

Interactive Discussion 
Resultant estimates of the water budget components as obtained from the final run for 1979-1993 are displayed in Fig. 6 in terms of annual time-series and model predicted evaporation and corrected ERA-15 precipitation are compared with corresponding estimates from Mamatov et al. (2004). As it is shown dynamics of predicted by 5 the model evaporation are in a good agreement with the estimates. Despite absolute magnitudes of predicted evaporation are slightly lower than the estimates they are well in the range of other available estimates (Table 2). Thus we assume that modeled evaporation data are reliable. Furthermore, modeled evaporation might be even more accurate than other estimates because of they are derived from a consideration of 10 small scale dynamical processes rather than from a pure water balance closure which is known to significantly bias the estimates (see discussion above).

\section{Results from the 3-D best guess hind cast}

\subsection{Water budget and salinity}

The results from the 3-D interactively drying and wetting model show a successful reproduction of observed sea level decrease for the hind cast period 1979-1993 within the 15-years simulation. Daily time-series of mean sea surface level (SSL) for the Large and Small Aral basins as well as for the total Aral Sea are compared with observed annual values published by Chub (2000) (Fig. 7a). Modeled total SSL variability within the 15-years simulation deviates from the observed values in the order of a few 20 centimeters only. Maximum deviations are found for the years 1990 and 1991 and are in the order of $0.5 \mathrm{~m}$. On a top of the continuous SSL decrease, the model results show a clear seasonal cycle. Significant sea level dropping of $5-15 \mathrm{~cm} /$ month occurs in the period from May to November in the total Aral Sea. In the rest of the year SSL is mostly unchanged or may slightly increase in February-March. Similar seasonal SSL variations were detected from analysis of Topex/Poseidon altimeter data, sampled over the Aral Sea with a temporal resolution of 10 days for the period 1992-2001 (Peneva

\section{GMDD}

1, 243-283, 2008

The Aral Sea shrinking by a 3-D model ECOSMO

I. Alekseeva and C. Schrum

\section{Title Page}

Abstract Introduction

Conclusions

Tables

References

Figures

14

4

Back

Full Screen / Esc

Printer-friendly Version

Interactive Discussion 
et al., 2004; Stanev et al., 2004). The accurate prediction of seasonality reflects a correct representation of seasonal signals in fresh water fluxes and further proves that the chosen strategy of the model setup is successful.

The model was furthermore able to realistically predict the separation of the Aral Sea 5 into the Large and Small Seas, which was reported to happen for the first time in 1988. However, it is not clear whether the Small and the Large Aral were again connected and when possible re-connections occurred (Peneva et al., 2004). In 1991 a dam was build to preserve the separation in order to stabilize sea level in the Small Aral Sea. According to model results the Aral Sea division occurred in the second half of 1988 10 and a short time re-connection took place in January 1989 (Fig. 7a). The ability of the sea-ice model to account for separation of the model domain into individual basins in relation with sea surface level lowing allows for further accurate simulations of the Aral Sea development after 1988. After the division of the Aral Sea, the Large and Small seas behaved differently (EU-INTAS 1014 and 1003, 2004). The sea level in the Small

15 Aral was stabilized due to dominating fresh water input (Salokhiddinov and Khakimov, 2004) and the Large Aral continued to shrink. The model results realistically describe these changes (Fig. 7a). Already in $1991 \mathrm{SSL}$ in the Small Aral was $0.7 \mathrm{~m}$ higher than in the Large Aral. The Large Aral shrinking continued at the same rates as before and the Large Aral sea level dropped by $5.4 \mathrm{~m}$ during 1988-1993.

20 Predicted long-term trends of Aral Sea area and volume are presented in Fig. $7 \mathrm{~b}$ in comparison with estimates provided by Mamatov et al. (2004). The modeled sea area decreased from $52 \times 10^{3}$ to $36 \times 10^{3} \mathrm{~km}^{2}$ and corresponding changes in volume were from 705 to $301 \mathrm{~km}^{3}$. In the end of the simulation in 1993, the Large Aral covered only $34 \times 10^{3} \mathrm{~km}^{2}$ and had a volume of $280 \mathrm{~km}^{3}$. Independent estimates of the Large Aral 25 area and volume and accounted for $35 \times 10^{3} \mathrm{~km}^{2}$ and $270 \mathrm{~km}^{3}$ in 1993 (Stanev et al., 2004) which is in close agreement with model results. However changes in the Aral Sea area and its volume as given by Mamatov et al. (2004) (Fig. 7b) are different. As it was already mentioned (see Fig. 4 and discussion in Sect. 2), estimates of these geometric parameters were derived involving known SSL and hypsometric relations,

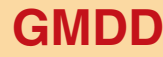

$1,243-283,2008$

The Aral Sea shrinking by a 3-D model ECOSMO

I. Alekseeva and C. Schrum

Title Page

Abstract

Conclusions

Tables

Figures

14

4

Back

Full Screen / Esc

Printer-friendly Version

Interactive Discussion 
based on topographic data. Differences in the estimates can be explained by different topography used by different authors. The model topography was found to be similar to that used by Stanev et al. (2004) and thus provided estimates are comparable with modeled results while estimates provided by Mamatov are drastically different.

5 Results of the model simulation for 1979-1993 in terms of temperature and salinity are demonstrated in Fig. 8, daily modeled time-series averaged in the total Aral Sea and in the Small and Large seas are displayed. Modeled salinity in the total Aral is also compared with observational annual data (Mamatov et al., 2004). In the model setup we neglected sources of salt such as salt depletion on the dried sea bed, salt inflow 10 from mineralized river and groundwater and chemical salt precipitation and evaporation. It is difficult to evaluate these processes however their respective contribution often is suggested to be more significant with increasing mineralization of the Aral Sea (Benduhn and Renard, 2004; Peneva et al., 2004). Although employing a salt conservative approach in the sea-ice model we neglected these sources and sinks modeled 15 values of salinity are very close to observations. It suggests that contributions of the sources and sinks in the salt balance were of small importance in the considered period or they might cancel out each other. In the period of the simulation salinity in the total Aral increased from 15 to $36 \%$. Averaged salinity in the Small Aral was slightly less than in the Large Aral in 1979-1988 suggesting that the salinity increase in the 20 Small Aral was maintained by saline water inflow from the Large Aral, which served as a main evaporator. After 1988 when the Large Aral and the Small Aral disconnected, salinity in the Small Aral stabilized at $26 \%$.

\subsection{Modeled ice}

Main observational data on ice characteristics in the Aral Sea are available from satel25 lite altimetry, which becomes the only source of data since historical data of in situ measurements and aerial surveys end in mid 1980s. There are three satellites providing data on the ice cover in the Aral Sea: NIMBUS-7 with the Scanning Multichannel Microwave Radiometer (SMMR) onboard operating in the period 1979-1987, the

GMDD

$1,243-283,2008$

The Aral Sea shrinking by a 3-D model ECOSMO

I. Alekseeva and C. Schrum

Title Page

Abstract

Conclusions

Tables

Figures

14

4

Back

Full Screen / Esc

Printer-friendly Version

Interactive Discussion $\rightarrow 1$

Close 
Defence Meteorological Satellite Program with the Special Sensor Microwave/Imager (SSM/I) operating since 1987 and TOPEX/Poseidon with a radiometer and radar altimeter (since 1992).

Available historical observations (Bortnik and Chistyayeva, 1990) and the satellite 5 data were combined and evaluated by Kouraev et al. (2004), the resultant datasets provide unique continuous time-series of ice extent and duration of ice period in the Large Aral for 1978-2002. Their results indicate a regular formation of sea-ice in the Aral Sea each year with pronounced inter-annual variability influenced by regional climatic factors.

10 Evidences from historical records (Kouraev et al., 2004) highlighted spatial-temporal dynamics of ice conditions in the Aral Sea in different by thermal conditions years. The duration of the ice period was observed to vary between 80 and 120 days, starting from the middle of November-January and lasting till the end of March-beginning of April. The beginning of ice formation as well as the most severe ice conditions occurred in the northern and eastern parts of the Aral Sea. The whole Small Aral and parts along the eastern and southern coast of the Large Aral were covered by ice in January. The maximal ice extent was observed in February-March, when ice occupied up to $80 \%$ of the Aral Sea surface area in cold winters and less than $20 \%$ in warm winters. The maximum ice thickness was observed also in February-March and reached $0.7 \mathrm{~m}$ in the northern and $0.3-0.45 \mathrm{~m}$ in the southern parts on average. The seasonal melting of ice began in the second half of February or the first half of March. Corresponding characteristics of ice conditions (duration of ice seasons, first and last days of ice presence and area covered with ice) in the Large Aral were derived from the sea-ice model results for 1973-1993 and are shown in Fig. 9. The duration of the modeled ice period 25 ranges from 80 to 140 days with the begging of ice seasons in the end of NovemberJanuary and the maximum ice extent predicted in February-March when ice covered area may reach $90 \%$ of the Large Aral surface area in cold years and it is less than $10 \%$ in mild years. That is in good agreement with observational data; however model predicts the earliest beginning of ice seasons detected in the winter 1987/1988 1-2
The Aral Sea shrinking by a 3-D model ECOSMO

I. Alekseeva and C. Schrum

Title Page

Abstract Introduction

Conclusions

Tables References Figures

14

4

Back

Full Screen / Esc

Printer-friendly Version

Interactive Discussion 
weeks later. The ice development for the period February-March as simulated by the sea-ice in the extreme cold year 1984 and the mild year 1986 are illustrated in Fig. 10. It is shown that before the maximum ice extent occurred (the beginning of February) in both the mild and cold winters, ice already covered the Small Aral and northern parts 5 of the Large Aral. In the cold year almost the whole Aral Sea was covered by ice in the middle of March. Ice thickness reached a maximum of $1.8 \mathrm{~m}$ in the extreme cold year 1984 and in the mild year ice thickness was less than $0.5 \mathrm{~m}$. In the end of the ice seasons melting was observed first to occur at the shallow western coastal zone.

We used time-series of winter integrated ice extent based on the SMMR and SSM/I 10 data (Kouraev et al., 2004) to validate the sea-ice model in terms of inter-annual variability (Fig. 11). The satellite time-series were computed as a total number of pixels classified as ice during each winter within the inner area of the Large Aral bounded by the coastline location in 1992. The source SMMR and SSM/I data have been resolved on a horizontal regular grid with a nominal cell size of $25 \mathrm{~km} \times 25 \mathrm{~km}$ and the temporal resolution of 5 days. Modeled time-series of the ice-covered area were calculated from the modeled ice extent and ice compactness, which are available on the model grid $(5 \mathrm{~km} \times 5 \mathrm{~km})$ with daily resolution, and were integrated over each winter. A comparison of the time-series indicates that the model reproduced the observed ice dynamics well, a linear correlation between the time-series accounts for 0.65 . One can note that there are only two winters 1985/86 and 1986/87, which are warm winters in accordance with model results, when the modeled ice outstandingly significant deviates from observations. Excluding them from the considered time-series the correlation increases up to 0.87 indicating very high model performance. Possible reasons of the discrepancies between the modeled and satellite data in the ice seasons 1985/86 and 1986/87 may arise due to uncertainties in both the sea-ice model and/or satellite derived data. The latter have a relatively coarse spatial resolution and do not cover coastal parts of the Large Aral and thus may tend to underestimate variability of ice extent between warm years.

\section{GMDD}

1, 243-283, 2008

The Aral Sea shrinking by a 3-D model ECOSMO

I. Alekseeva and C. Schrum

\section{Title Page}

Abstract Introduction

Conclusions

Tables References Figures

14

Back

Full Screen / Esc

Printer-friendly Version

Interactive Discussion 


\section{Conclusions}

With the model presented here a tool is provided for a historical reconstruction of the water budget in the Aral Sea as a function of a minimum number of external processes including precipitation and runoff. To our knowledge it was for the first time possible 5 to consider local mesoscale dynamics in the Aral Sea in conjunction with an accurate description of rapidly decreasing sea surface area and sea volume and thus to account for evaporation and its impact on the water balance. The sea-ice model was able to reproduce the surface level lowing of $10 \mathrm{~m}$ in the 15 year period of model simulation as well as realistic salinization and ice conditions in Aral Sea.

The sea-ice model ECOSMO with implemented wetting and drying technique comprises a powerful tool among a variety of simple models (e.g. Bortnik 1996; Salokhiddinnov and Khakimov, 2004; Benduhn and Renard, 2004; Peneva et al., 2004; Vasiliev et al., 2006) used to account for the Aral Sea water balance. It has also advantages in assessment of the Aral Sea local processes in comparison with coupled regional climate-lake models (Small et al., 1999) due to the sea-ice model resolves the Aral Sea hydrodynamics and air-sea turbulent fluxes in conjunction with the Aral Sea changing geometry and its salinization. The model provides an opportunity for investigation of different aspects of the Aral Sea environmental changes for instance estimates of water budget components including modelled evaporation, changes in general circulation patterns and heat content in dependence on changing of coastal line positions and increasing salinity, assessment of water masses exchange between Aral Sea basins. Recently, the sea-ice model has been used to study groundwater-seawater interactions during the Aral Sea shrinking, model sensitivity tests were also carried out to address effects of salinity on the thermodynamics, ice formation and evaporation (Alekseeva et al., 2008). The model thereby contributes to the predictive capacity in environmental management and can be used for scenario testing on different water management strategies as well for climate change impact studies.

Although our model implementation is a clear improvement for water budget model-
The Aral Sea shrinking by a 3-D model ECOSMO

I. Alekseeva and C. Schrum

\section{Title Page}

Abstract

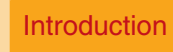

Conclusions

Tables

References

Figures

14

Back

Full Screen / Esc

Printer-friendly Version

Interactive Discussion 
ing it must be further improved in order to simulate recent conditions in the Aral Sea associated with ongoing shrinking and increasing mineralization. Small water bodies which appear while shrinking are still neglected in the model. However they may influence water mass, thermal energy and salt balance in the sea while slowly evaporating (Peneva et al., 2004). It is also become important to account for the salt composition and non-hydrostatic effects with increasing salinity.

Acknowledgements. The research was funded by the EU-INTAS, grant number INTAS-ARAL00-1004, and by the German Research foundation (DFG) under grant number SCHR 666/2-1. The authors are grateful to the project members of the INTAS projects 1003 and 1014 for their open and helpful cooperation, for fruitful discussions on the topic and for their contributions to the ASGIS database.

\section{References}

Aladin, N. V. and Williams, W. D.: Recent changes in the biota of the Aral Sea, Central Asia, Verh. Internat. Verein. Limnol., 25, 790-792, 1993.

15 Alekseeva, I., Jarsjö, J., Schrum, C., and Destouni, G.: Reproducing the Aral Sea water budget and sea-groundwater dynamics between 1979 and 1993 using a coupled 3-D sea-icegroundwater model, J. Mar. Syst., doi:10.1016/j.jmarsys.2008.03.018, in press, 2008.

Backhaus, J. O.: Zur Hydrodynamik im Flachwassergebiet. Ein numerisches Modell, Dtsch. Hydrogr. Z., 29, 222-238, 1976.

Balzano, A.: Evalution of methods for numerical simulation of wetting and drying in shallow water flow, Coast. Eng., 83-107, 1998.

Benduhn, F. and Renard, P.: A dynamic model of the Aral Sea water and salt balance, J. Mar. Syst., 47, 35-50, 2004.

Bortnik, V. N.: Changes in water level and hydrological balance of the Aral Sea, in: The Aral Sea Basin, NATO ASI Series, edited by: Micklin, P. P. and Williams, W. D., Partnership SubSeries, 2. Environment, Springer-Verlag, Berlin, 12., 25-32, 1996.

Bortnik, V. N. and Chistyaeva, S. P. (Eds.): Hydrometeorology and hydrochemistry of seas of the USSR, Project "Seas of the USSR", The Aral Sea, vol. II, Gidrometeoizdat, Leningrad, 195 pp., 1990 (in Russian).

\section{GMDD}

1, 243-283, 2008

The Aral Sea shrinking by a 3-D model ECOSMO

I. Alekseeva and C. Schrum

\section{Title Page}

Abstract Introduction

Conclusions

Tables References Figures

14

Back

Full Screen / Esc

Printer-friendly Version

Interactive Discussion 
Chernenko, I. M.: More about the Aral Sea problem, Problemy Osvonia Pustyn, 4, 53-57, 1987.

Chub, V. E.: Climate Change and its Impact on the Natural Resources Potential of the Republic of Uzbekistan, Hydrometeorological Service of Uzbekistan, 219 pp., 2000.

5 Dobson, F. W. and Smith, S. D.: Bulk Models of Solar Radiation at Sea, Q. J. Roy. Meteorol. Soc., 114, 165-182, 1988.

Fofonoff, N. P. and Millard Jr., R. C.: Algorithms for computation of fundamental properties of sea water, UNESCO Technical Papers in Marine Science, 44, 1983.

EU-INTAS Project 1014: Study of the Groundwater contribution to the Aral Sea Regiona Water Supply and Water Quality: Strategies for Reversibility and Pollution Control, Annual Report 2004, edited by: Schrum, C., 2004.

EU-INTAS 1014 and 1003: Annual Cluster Report 2004, edited by: Schrum, C., 2004.

Ferrari, M. R., Miller, J. R., and Russell, G. L.: Modeling the effect of wetlands, flooding, and irrigation on river flow: Application to the Aral Sea, Water Resour. Res., 35, 1869-1876, 1999.

Friedrich, J. and Oberhänsli, H.: Hydrochemical properties of the Aral Sea in summer 2002, J. Mar., 47, 77-88, 2004.

Gibson, R., Kallberg, P., and Uppala, S.: The ECMWF Re-Analysis (ERA) project, ECMWF Newsletter, 73, 7-17, 1996.

20 Glazovsky, N. F.: The salt balance of the Aral Sea, GeoJournal, 35.1, 35-41, 1995.

Harms, I., Schrum, C., and Hatten, K.: Numerical sensitivity studies on the variability of climate relevant processes in the Barents Sea, J. Geophys. Res., 110, C06002, doi:10.1029/2004JC002559, 2005.

Hübner, U. and Backhaus, J.: Strömungsmodell Nordsylter Wattenmeer, in: Umweltaltlas Wattenmeer Band 1: Nordfriesisches und Dithmarscher Wattenmeer, Hrsg.: Kohlus, J., 1996.

Idso, B. S. and Jackson, D. R.: Thermal radiation from the atmosphere, J. Geophys. Res., 74(23), 5397-5403, 1969.

Jarsjö, J. and Destouni, G.: Groundwater discharge into the Aral Sea after 1960, J. Mar. Syst., 47, 109-120, 2004.

so Kalnay, E., Kanamitsu, M., Kistler, R., Collins, W., Deaven, D., Gandin, L., Iredall, M., Saha, S., Withe, G., Woollen, J., Zhu, Y., Chelliah, M., Ebisuzaki, W., Higgens, W., Janowiak, J., Mo, K. C., Ropelewski, C., Wang, J., Leetma, A., Reynolds, R., Jenne, R., and Joseph, D.: The NCEP/NCAR 40-Year Reanalysis Project, B. Am. Meteorol. Soc., 77, 437-471, 1996.

\section{GMDD}

1, 243-283, 2008

The Aral Sea shrinking by a 3-D model ECOSMO

I. Alekseeva and C. Schrum

\section{Title Page}

Abstract

Introduction

Conclusions

Tables

References

Figures

14

4

Back

Full Screen / Esc

Printer-friendly Version

Interactive Discussion 
Khodjibaev, N. N.: Ground runoff and the Aral sea problem. Trudy Nauchno-Teknichesgkogo Soveshchaniya po Gidrologi i Inzhnernoi Geologii, 1, 53-58, 1968.

Kouraev, A. V., Papa, F., Mognard, N. M., Buharizin, P. I., Cazenave, A., Cretaux, J. F., Dozortseva, J., and Remy, F.: Sea ice cover in the Caspian and Aral Seas from historical and satellite data, J. Mar. Syst., 47, 89-100, 2004.

Launiainen, J. and Vihma, T.: Derivation of turbulent surface fluxes - an iterative flux-profile method allowing arbitrary observing heights, Environ. Softw., 5(3), 113-124, 1990.

Leendertse, J. J.: Aspectes of SIMSYS, A System for Two-Dimensional Flow Computation, RAND Publication R-3572-USGS, February 1987.

10 Legates, D. R. and Willmott, C. J.: Mean Seasonal and Spatial Variability in Guage-Corrected, Global Precipitation, Int. J. Climatol., 10, 111-127, 1990.

Mamatov, S. A., Medvedeva, L. A., and Yun, N. M.: Team report for EU-INTAS 1014 and 1003, 2004, Annual Cluster Report 2004, edited by: Schrum, C., 2004.

Oey, L.-Y., Ezer, T., Hu, C., and Muller-Karger, F. E.: Baroclinic tidal flows and inundation pro15 cesses in Cook Inlet, Alaska: Numerical modeling and satellite observations, Clim. Dynam., 57(3), 205-221, 2007.

Peneva, E. L., Stanev, E. V., Stanychni, S. V., Salokhiddinov, A., and Stulina, G.: The recent evolution of the Aral Sea level and water properties: analysis of satellite, gauge and hydrometeorological data, J. Mar. Syst., 47, 11-24, 2004.

20 Sadov, A. V. and Krasnikov, V. V.: Detection of foci of subaqueous subsurface water discharge into Aral Sea by remote sensing methods, Problemy Osvoeniya Pustyn, 1, 28-36, 1987.

Salokhiddinov, A. T. and Khakimov, Z. M.: Ways the Aral Sea behaves, J. Mar. Syst., 47, 127136, 2004.

Schrum, C.: A coupled ice-ocean model for the North Sea and the Baltic Sea. Sensitivity of North Sea, Baltic Sea and Black Sea to anthropogenic and climatic changes. Nato ASI Ser., Kluwer Academic Publishers, edited by: Özsoy, E. and Mikaelyan, A., 311-325, 1997a.

Schrum, C.: Thermohaline stratification and instabilities at tidal mixing fronts. Results of an eddy resolving model for the German Bight, Cont. Shelf Res., 17(6), 689-716, 1997b.

Schrum, C., Alekseeva, I., and St. John, M.: ECOSMO, a coupled ecosystem model of the North Sea and Baltic Sea. Part I: Model description and simulation of annual characteristics in the North Sea, J. Mar. Syst., 61, 79-99, doi:10.1016/j.jmarsys.2006.01.005, 2006.

Schrum, C. and Backhaus, J. O.: Sensitivity of atmosphere-ocean heat exchange and heat content in North Sea and Baltic Sea. A comparative Assessment, Tellus, 51A, 526-549,

\section{The Aral Sea shrinking by a 3-D model ECOSMO}

I. Alekseeva and C. Schrum

Title Page

Abstract

Introduction

Conclusions

Tables

References

Figures

14

4

Back

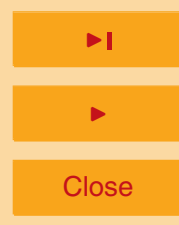

Full Screen / Esc

Printer-friendly Version

Interactive Discussion 
1999.

Sirjacobs, D., Gregoire, M., Delhez, E., and Nihoul, J. C. J.: Influence of the Aral Sea negative water balance on its seasonal circulation patterns: use of a 3D hydrodynamic model, J. Mar. Syst., 47, 51-66, 2004.

5 Small, E. E., Sloan, L. C., Hostetler, S., and Giorgi, F.: Simulating the water balance of the Aral Sea with a coupled regional climate-lake model, J. Geophys. Res., 104(D6), 6583-6602, 1999.

Small, E. E., Giorgi, F., Sloan, L. C., and Hostetler, S.: The effects of desiccation and climatic change on the hydrology of the Aral Sea, J. Climate, 14, 300-322, 2001.

10 Stanev, E. V., Peneva, E. L., and Mercier, F.: Temporal and spatial patterns of sea level in inland basins: Recent events in the Aral Sea, Geophys. Res. Lett., 31, L15505, doi:10.1029/2004GL020478, 2004.

Uppala, S. M., Kållberg, P. W., Simmons, A. J., Andrae, U., da Costa Bechtold, V., Fiorino, M., Gibson, J. K., Haseler, J., Hernandez, A., Kelly, G. A., Li, X., Onogi, K., Saarinen, S., Sokka, 15 N., Allan, R. P., Andersson, E., Arpe, K., Balmaseda, M. A., Beljaars, A. C. M., van de Berg, L., Bidlot, J., Bormann, N., Caires, S., Chevallier, F., Dethof, A., Dragosavac, M., Fisher, M., Fuentes, M., Hagemann, S., Hólm, E., Hoskins, B. J., Isaksen, L., Janssen, P. A. E. M., Jenne, R., McNally, A. P., Mahfouf, J. F., Morcrette, J. J., Rayner, N. A., Saunders, R. W., Simon, P., Sterl, A., Trenberth, K. E., Untch, A., Vasiljevic, D., Viterbo, P., and Woollen, J.: The ERA-40 re-analysis, Q. J. Roy. Meteorol. Soc., 131, 2961-3012, doi:10.1256/qj.04.176., 2005.

Vasiliev, O. F., Ovchinnikova, T. E., Semchukov, A. N., Prokopiev, S. I., levlev, K. V., and Korobkina, E. A.: Modelling of hydrological and hydrophysical processes in the western part of Aral Sea. The proceedings of International Scientific Conference "Extreme hydrological events in Aral and Caspian Sea region", Moscow, 2006.

Veselov, V.: Simulation of Groundwater Resources of Aral Sea Basin, Institute of Hydrogeology and Hydrophysics of the Ministry of Education and Science, Kazakhstan WWW Page, http: //www.aralmodel.unesco.kz, 2002.

Zavialov, P. O., Kostianoy, A. G., Emelianov, S. V., Ni, A. A., Ishniyazov, D., Khan, V. M., and 30 Kudyshkin, T. V.: Hydrographic survey in the dying Aral Sea, Geophys. Res. Lett., 30(13), 1659, doi:10.1029/2003GL017427, 2003.

\section{GMDD}

1, 243-283, 2008

The Aral Sea

shrinking by a 3-D model ECOSMO

I. Alekseeva and C. Schrum

\section{Title Page}

Abstract Introduction

Conclusions

Tables

References

Figures

14

4

Back

Full Screen / Esc

Printer-friendly Version

Interactive Discussion 


\section{GMDD}

1, 243-283, 2008

The Aral Sea shrinking by a 3-D model ECOSMO

I. Alekseeva and C. Schrum

Table 1. Threshold values in $\mathrm{cm}$ for the 6 different sensitivity experiments.

\begin{tabular}{cccccc}
\hline Exp. & Drying & Wetting & Exp. & Drying & Wetting \\
\hline EXP 1 & 10 & 15 & EXP 4 & 5 & 15 \\
EXP 2 & 10 & 10 & EXP 5 & 5 & 10 \\
EXP 3 & 10 & 40 & EXP 6 & 5 & 40 \\
\hline
\end{tabular}

Title Page

Abstract

Conclusions

\section{Tables}

14

4

Back

Full Screen / Esc

Printer-friendly Version

Interactive Discussion 
Table 2. The ranges of water balance terms precipitation, evaporation and river runoff derived from literature $\left(\mathrm{km}^{3} \mathrm{yr}^{-1}\right)$.

\begin{tabular}{lcclll}
\hline & $\mathrm{km}^{3} \mathrm{yr}^{-1}$ & Period & Data source & Reference & Area of the sea \\
\hline Precipitation & 11 & $1920-1980$ & Observations & Small et al. (1999) & $53 \times 10^{3} \mathrm{~km}^{2}$ \\
Precipitation & $9,5-11$ & $1988-1992$ & Model results & Small et al. (1999) & $44-38 \times 10^{3} \mathrm{~km}^{2}$ \\
Precipitation & 5.5 & $1981-1990$ & Calculated & Bortnik (1996) & $41-51 \times 10^{3} \mathrm{~km}^{2}$ \\
Precipitation & 7.2 & $1981-1990$ & Observed (Muynak) & Mamatov et al. (2004) & \\
Precipitation & 9.9 & $1979-1993$ & Model results Re-analysis & Gibson et al. (1996) & $35-53 \times 10^{3} \mathrm{~km}^{2}$ \\
Precipitation & 6.9 & $1981-1985$ & Model results & Benduhn and Renard (2004) & \\
Runoff & 4.2 & $1981-1990$ & Calculated & Bortnik (1996) & \\
Runoff & 2.46 & $1981-1985$ & Calculated & Sirjacobs et al. (2004) & \\
Runoff & 5.2 & $1981-1990$ & Observed & Mamatov et al. (2004) & \\
Evaporation & 55.1 & $1981-1985$ & Calculated & Benduhn and Renard (2004) & \\
Evaporation & 39 & $1981-1990$ & Calculated & Bortnik (1996) & $41-51 \times 10^{3} \mathrm{~km}^{2}$ \\
Evaporation & 40.2 & $1981-1990$ & Observed/Calculated & Mamatov et al. (2004) & \\
\hline
\end{tabular}

\section{The Aral Sea \\ shrinking by a 3-D model ECOSMO}

I. Alekseeva and C. Schrum

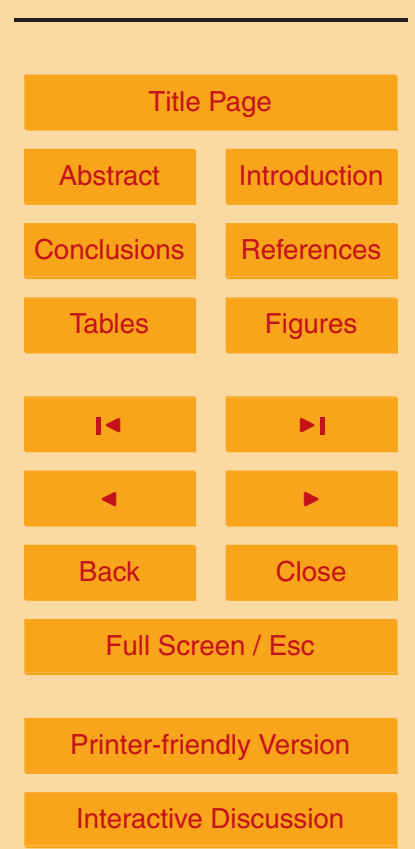




\section{GMDD}

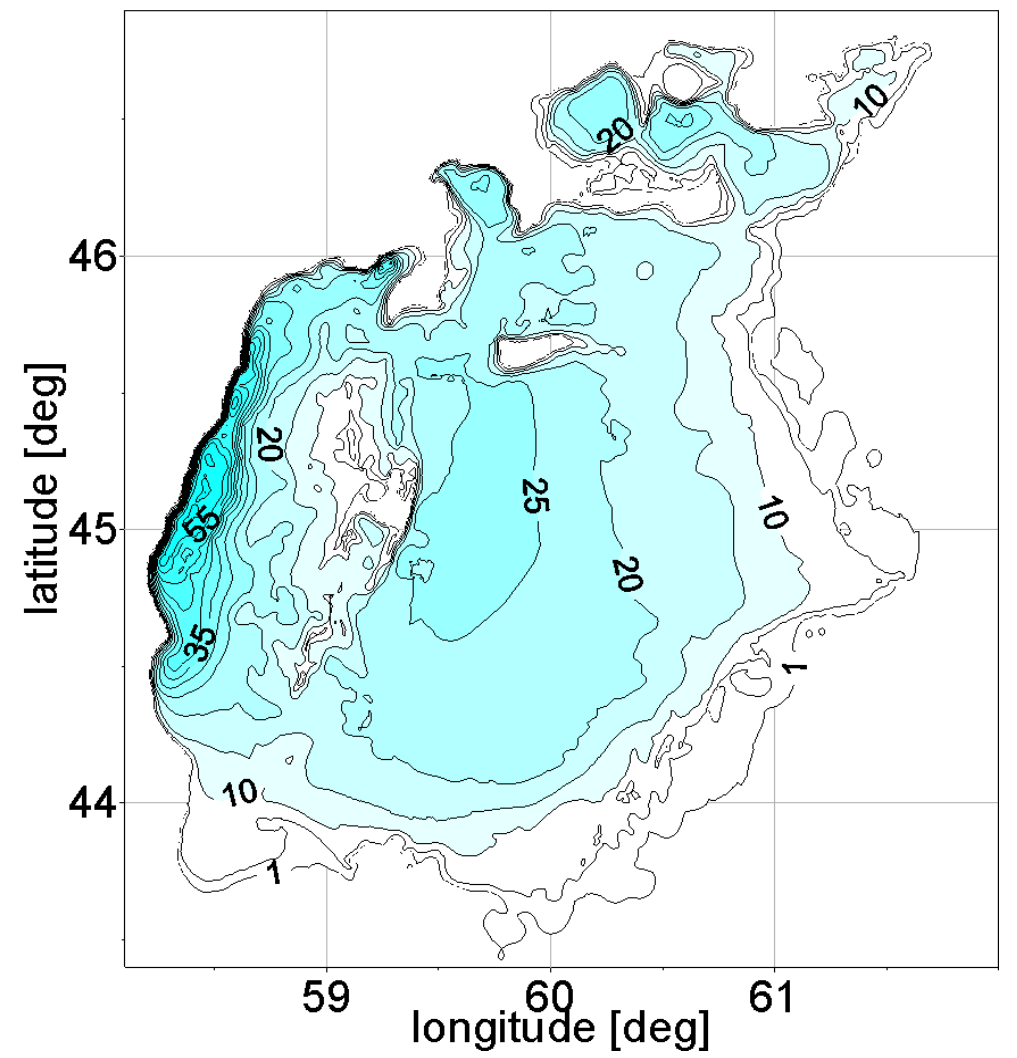

1, 243-283, 2008

The Aral Sea shrinking by a 3-D model ECOSMO

I. Alekseeva and C. Schrum

Title Page

Abstract

Introduction

Conclusions

References

Tables

Figures

14

$>1$

4

Back

Close

Full Screen / Esc

Printer-friendly Version

Interactive Discussion 
GMDD

$1,243-283,2008$

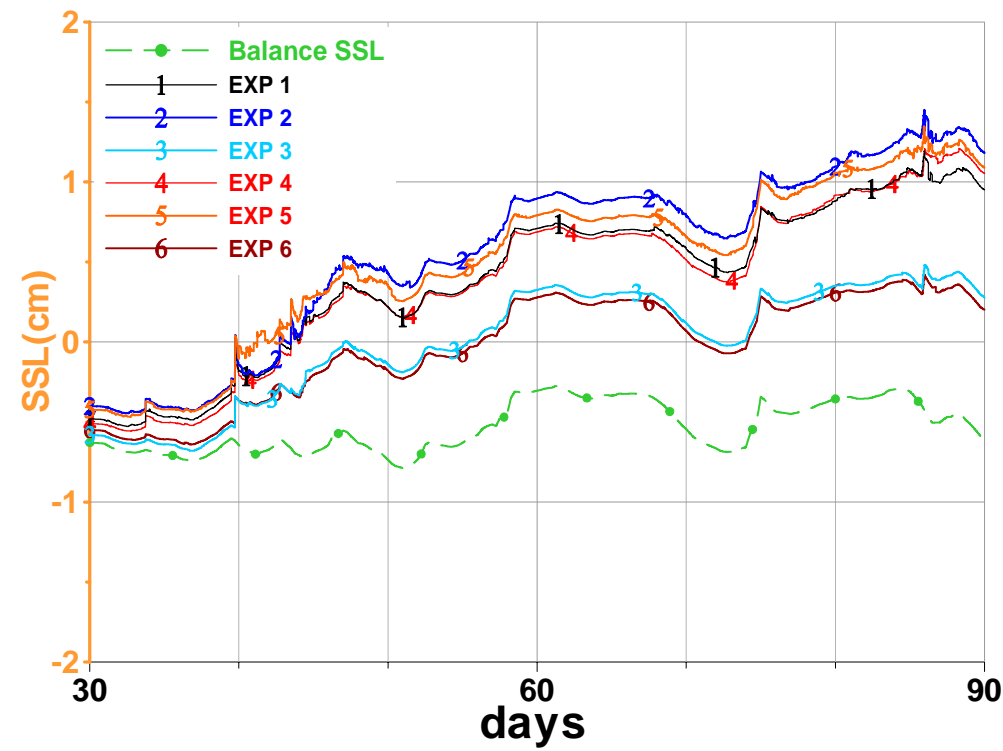

Fig. 2. Average sea level variations for the different sensitivity experiments starting on 1 January 1979. For reference the "Balance SSL" curve is given, which is estimated from the total volume budget.
The Aral Sea shrinking by a 3-D model ECOSMO

I. Alekseeva and C. Schrum

Title Page
Abstract

Conclusions

\section{Tables}

14

4

Back
Introduction

References

Figures

$>$ I

$>$

Close
Full Screen / Esc

Printer-friendly Version

Interactive Discussion 


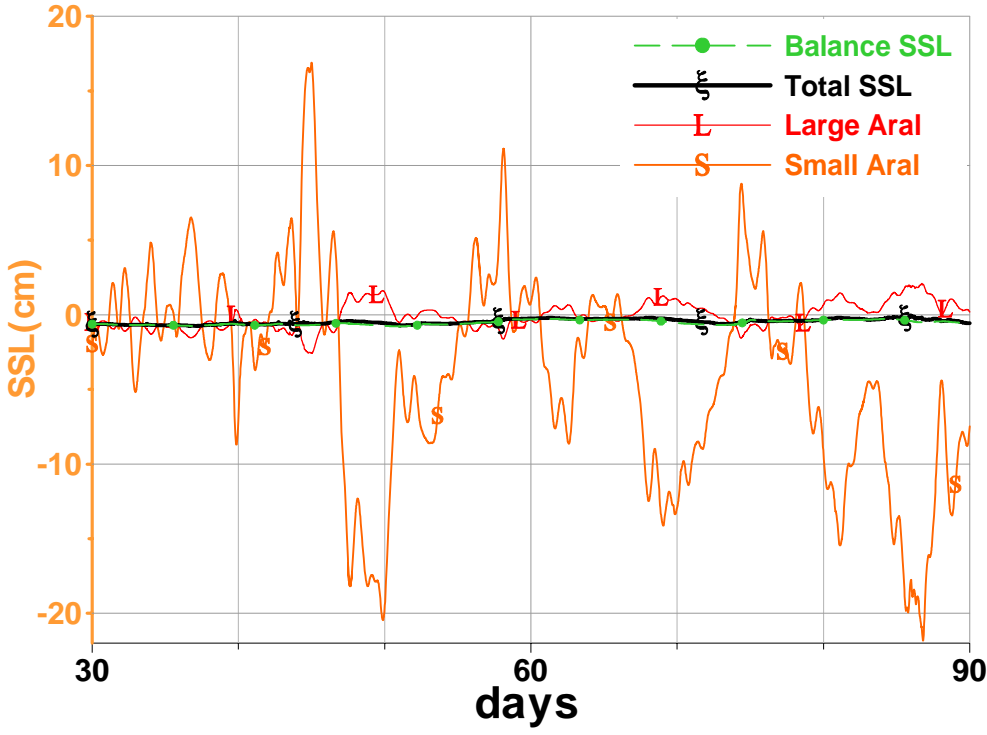

Fig. 3. Calculated sea level change for the test-case period January-March 1979. Final choice of thresholds and volume conserving numerical implementation of wetting and drying.
The Aral Sea shrinking by a 3-D model ECOSMO

I. Alekseeva and C. Schrum

\section{Title Page}

Abstract Introduction

Conclusions References

Tables Figures

14 $\rightarrow 1$

4

Back

Close

Full Screen / Esc

Printer-friendly Version

Interactive Discussion 


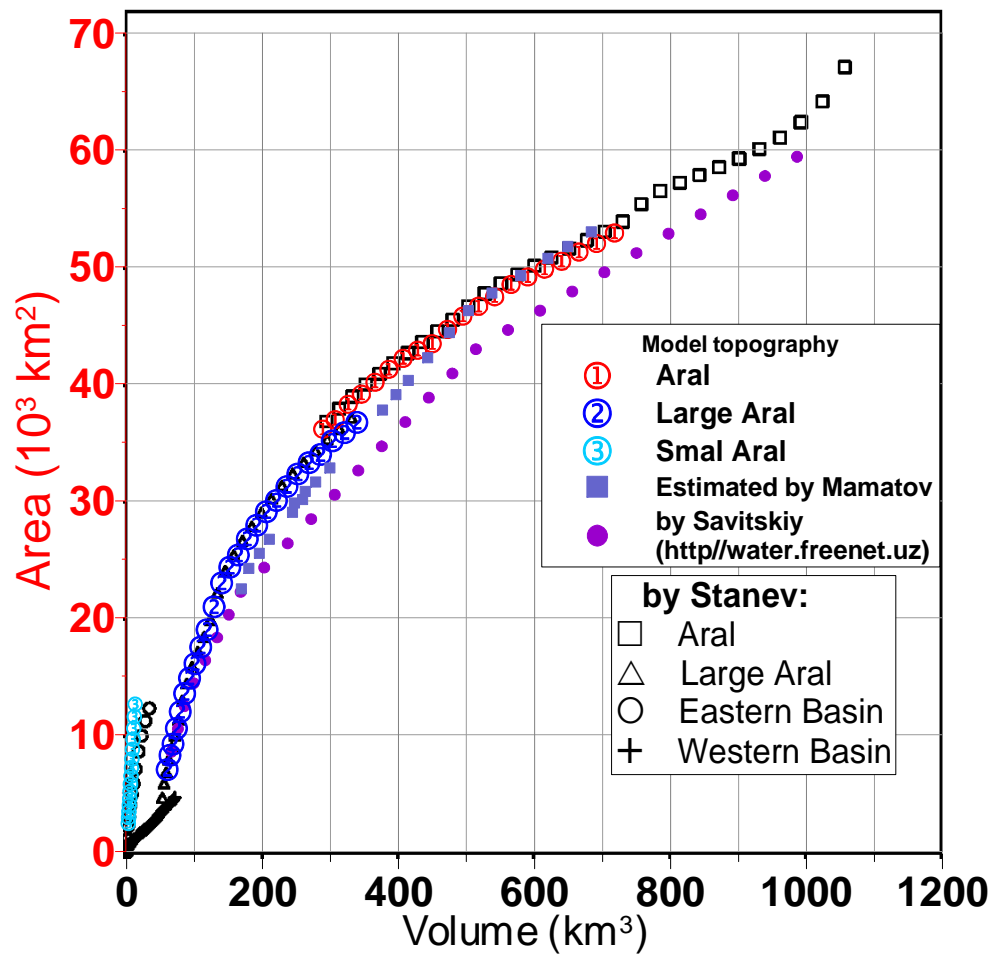

$1,243-283,2008$

The Aral Sea

shrinking by a 3-D model ECOSMO

I. Alekseeva and

C. Schrum

Title Page

Abstract

Introduction

Conclusions

References

Tables

Figures

14

- I

4

Back

Close

Full Screen / Esc

Fig. 4. Different hypsometric relations estimated from the model topography $(1,2,3)$, provided by Mamatov et al. (2004) (filled squares) and Savitskiy (http://water.freenet.uz) (filled circles) and published by Stanev et al. (2004) (symbols).

Printer-friendly Version

Interactive Discussion 


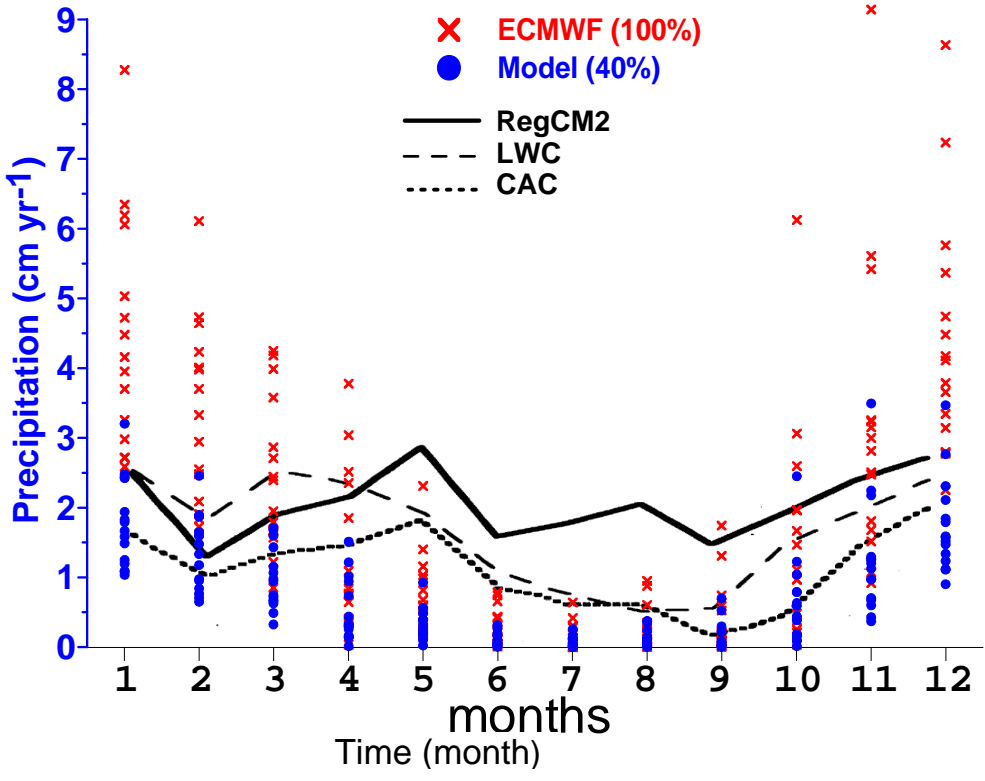

Fig. 5. Averaged over the Aral Sea monthly precipitation from ECMWF ERA-15 for years 19791993 (red crosses: uncorrected ERA-15 data; blue dots: reduced ERA-15 data). For validation purposes other independent estimates of precipitation are provided (adopted from Small et al., 1999): calculated annual cycle from RegCM2 (solid line, Small et al., 1999), CAC climatology (dotted, Climate Analysis Center) and LWC climatology (dashed, Legates and Willmot, 1990).
The Aral Sea shrinking by a 3-D model ECOSMO

I. Alekseeva and C. Schrum

\section{Title Page}

\section{Abstract}

Conclusions

Tables

14

4

Back
Introduction

References

\section{Figures}

$>1$

Close
Full Screen / Esc

Printer-friendly Version

Interactive Discussion 


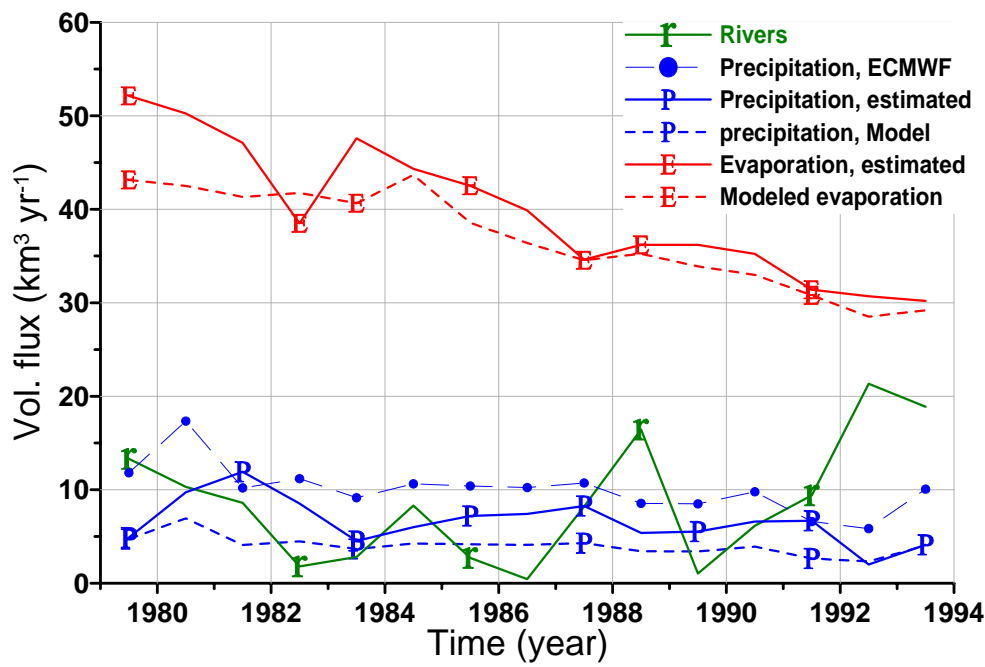

Fig. 6. Annual magnitudes of the main water balance components. Observed river runoff (Kiziljar, and Kazalinsk stations). Precipitation from ERA-15 data and estimated precipitation in comparison with corrected ERA-15 precipitation data for the model experiment. Estimated evaporation in comparison with evaporation predicted by the model. Estimations are made by Mamatov et al. (2004).
The Aral Sea shrinking by a 3-D model ECOSMO

I. Alekseeva and C. Schrum

\section{Title Page}

\section{Abstract}

Introduction

Conclusions

References

Tables

Figures

14

$\rightarrow 1$

4

Back

Close

Printer-friendly Version

Interactive Discussion 


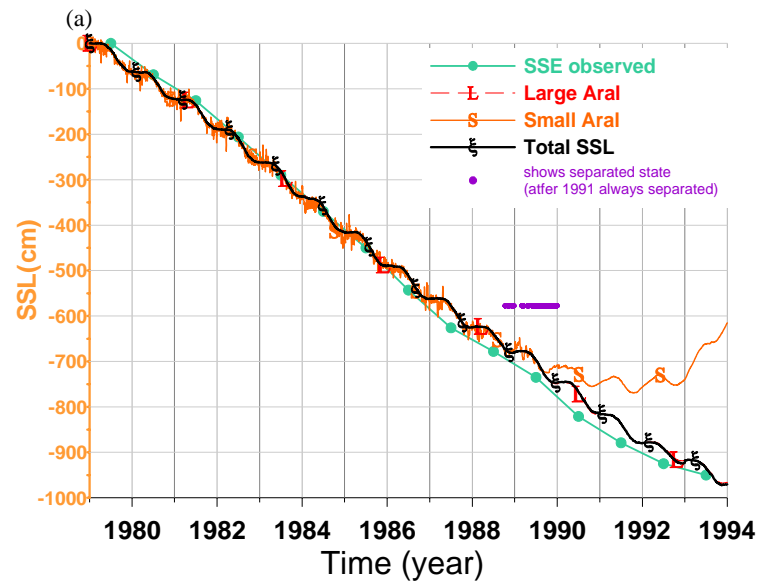

GMDD

1, 243-283, 2008

The Aral Sea shrinking by a 3-D model ECOSMO

I. Alekseeva and C. Schrum

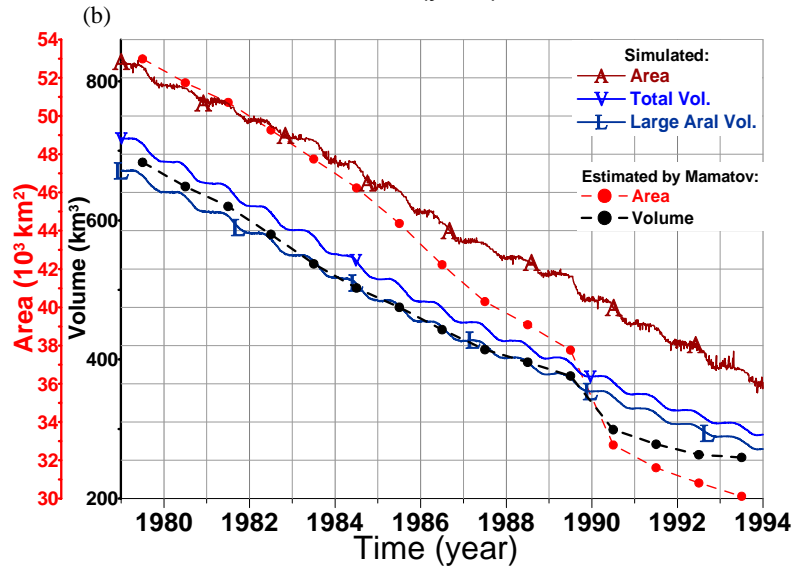

Title Page

Abstract

Conclusions

Tables

14

4

Back
Introduction

References

Figures

$\rightarrow 1$

$\checkmark$

Close

\section{Full Screen / Esc}

Printer-friendly Version

Fig. 7. (a) Modeled daily sea surface level variation compared to observed annual sea levels (Chub, 2000) and (b) modeled sea area and volume changes compared to estimations of Mamatov et al. (2004).

Interactive Discussion 


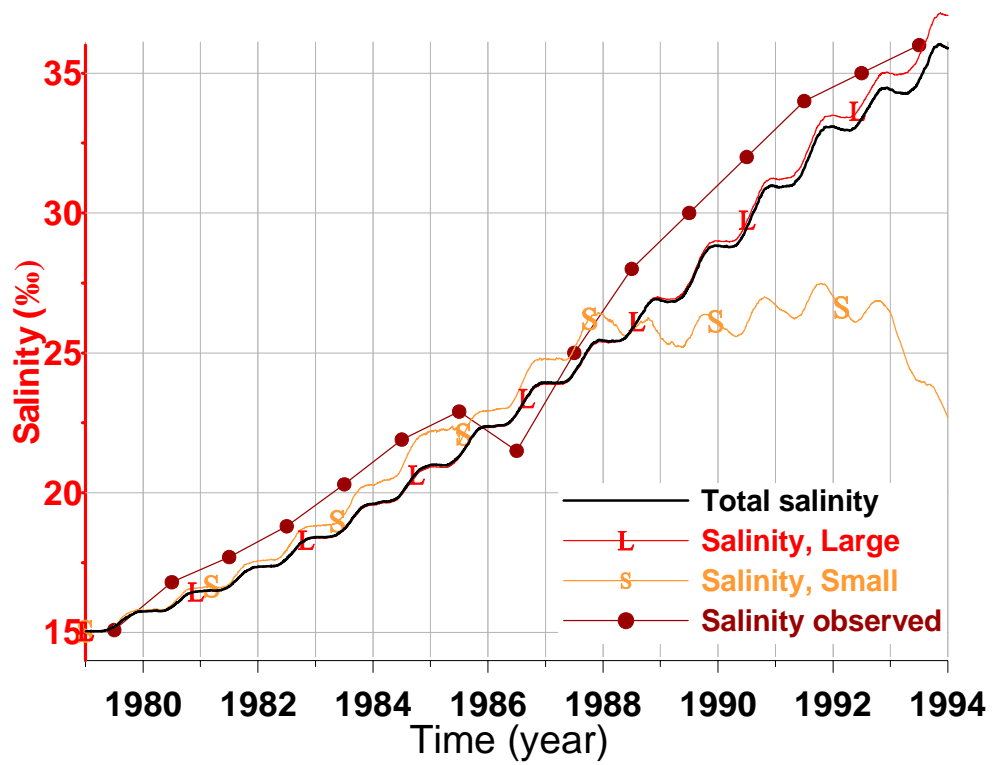

Fig. 8. Modeled daily time-series of salinity averaged in the total Aral Sea (black line) and in the Large (symbol L) and Small (symbol S) seas compared to observed annual salinity data in the total Aral Sea provided by Mamatov et al. (2004).
The Aral Sea shrinking by a 3-D model ECOSMO

I. Alekseeva and C. Schrum

Title Page
Abstract

Conclusions

\section{Tables}

14

4

Back
Introduction

References

Figures

$\rightarrow 1$

$\checkmark$

Close
Full Screen / Esc

Printer-friendly Version

Interactive Discussion 


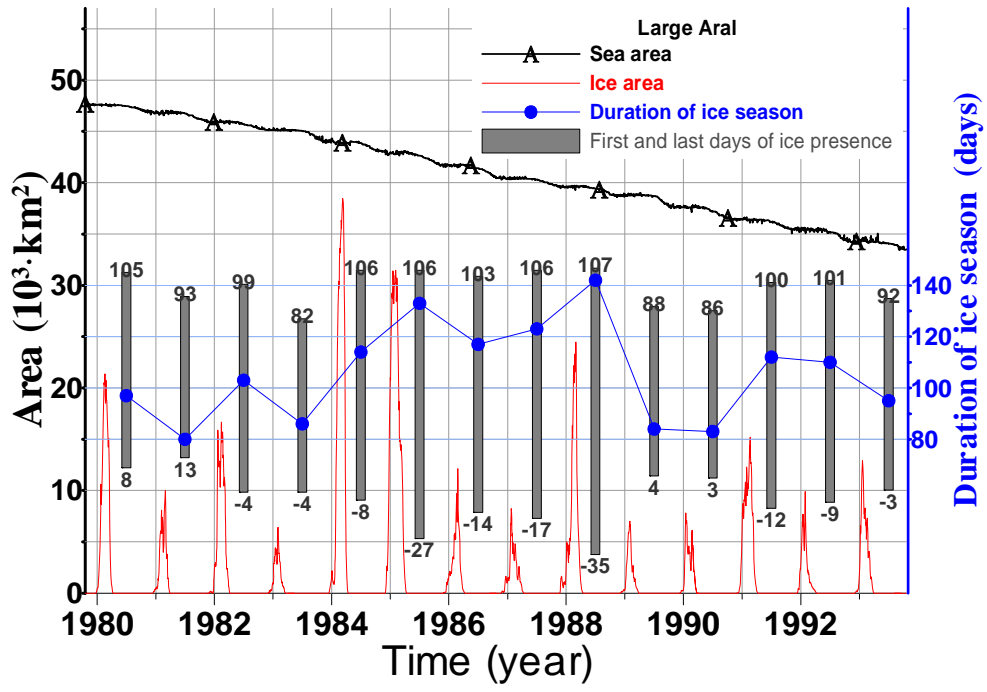

Fig. 9. Modeled ice dynamics in the Large Aral. Daily time-series of ice covered area and duration of ice period. In addition the first and the last days of ice season (days relative 1 January) and dynamics of shrinking sea area are shown.
The Aral Sea shrinking by a 3-D model ECOSMO

I. Alekseeva and C. Schrum

\section{Title Page}

\section{Abstract}

Conclusions

Tables

14

Back
Introduction

References

Figures

$\rightarrow 1$

Close

\section{Full Screen / Esc}

Printer-friendly Version 

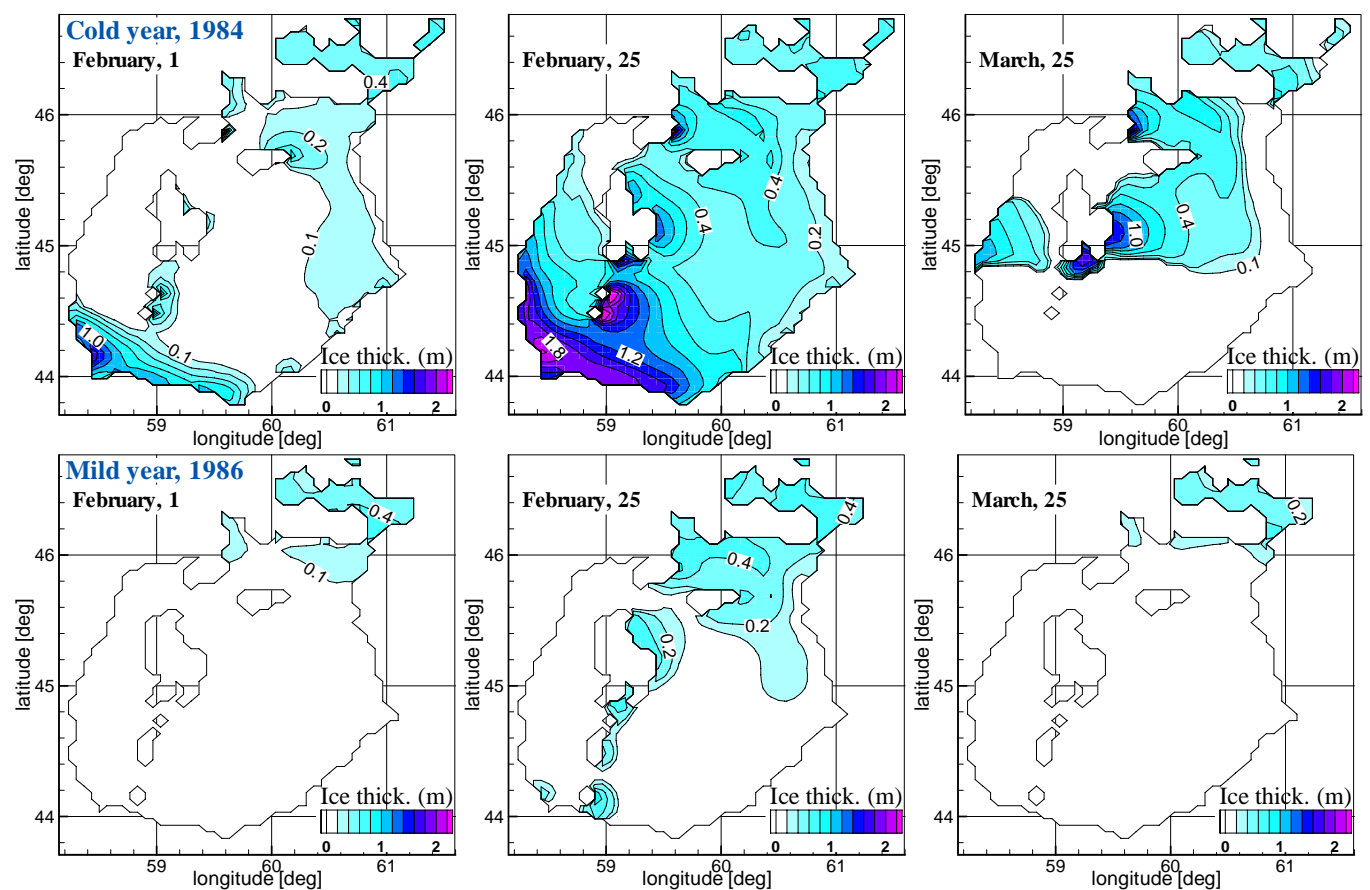

Fig. 10. Daily snapshots of modeled ice thickness for the extreme cold year 1984 (upper) and the mild year 1986 (bottom). The snapshots track stages of the ice development: before the maximum of ice extend (left), the maximum of ice extend (center) and the seasonal ice melting (right). Color represents ice thickness in [m], white area is ice free.
GMDD

1, 243-283, 2008

The Aral Sea

shrinking by a 3-D model ECOSMO

I. Alekseeva and C. Schrum

\section{Title Page}

\section{Abstract}

Introduction

Conclusions

References

Tables

Figures

14

$\rightarrow 1$

4

Back

Close

\section{Full Screen / Esc}

Printer-friendly Version 


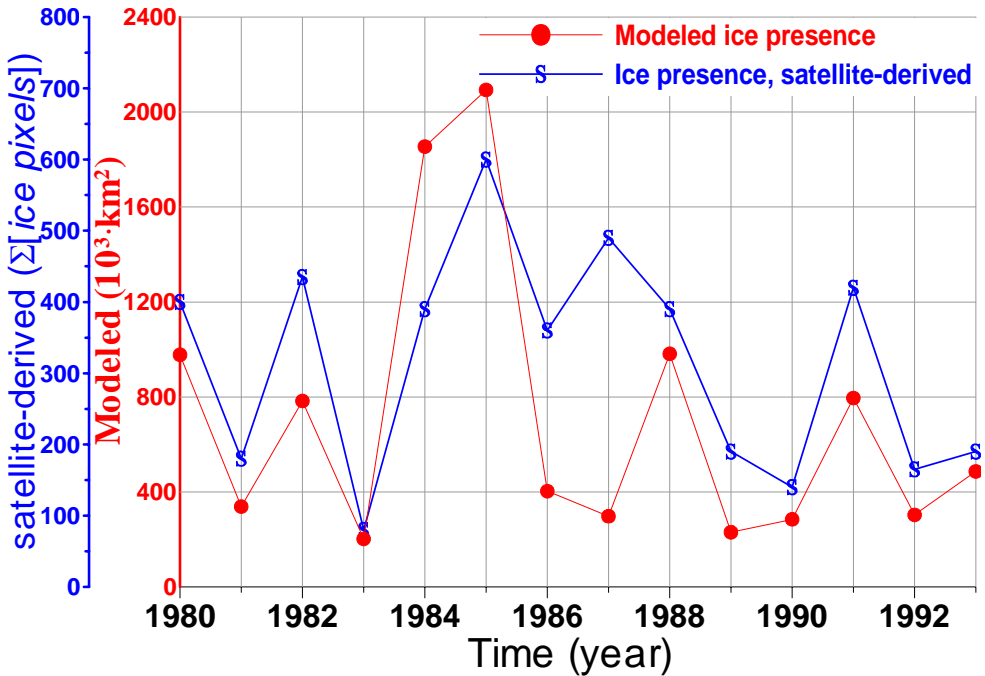

Fig. 11. Winter integrated ice extent in the Large Aral as derived from the sea-ice model (red dotted) and from satellite data (blue "S" symbols) as presented by Kouraev et al. (2004). The modeled values are ice covered area integrated for each winter $\left(10^{3} \mathrm{~km}^{2}\right)$. The satellite data account for total numbers of pixels classified as ice for each winter in the central Large Aral. The time axis labels correspond to new years.
The Aral Sea shrinking by a 3-D model ECOSMO

I. Alekseeva and C. Schrum

\section{Title Page}

\section{Abstract}

Conclusions

\section{Tables}

14

4

Back
Introduction

References

\section{Full Screen / Esc}

Printer-friendly Version 